\title{
Implementasi Pemberian Air Susu Ibu (ASI) Ekslusif
}

\author{
Derry Trisna Wahyuni* \\ Akademi Analis Kesehatan Putra Jaya Batam,trisna_derry@yahoo.com
}

\begin{abstract}
ABSTRAK
Menyusui sejak dini mempunyai peran penting yang fundamental pada kelangsungan hidup bayi.Kolostrum kaya dengan zat antibodi, pertumbuhan yang baik, kesehatan dan gizi bayi. Mengurangi morbiditas dan mortalitas bayi dan balita, Inisiasi Menyusu Dini (IMD) mempunyai peran penting bagi ibu dalam merangsang kontraksi uterus sehingga mengurangi perdarahan pasca melahirkan (postpartum). Menyusui dalam jangka panjang dapat memperpanjang jarak kelahiran karena masa amenorhea lebih panjang, pemulihan status gizi yang lebih baik sebelum kehamilan berikutnya. Menurut hasil Survei Sosial dan Ekonomi Nasional (Susenas), cakupan pemberian ASI eksklusif pada tahun 2007 berkisar 28,6\%, Riset Kesehatan Dasar (2010) menunjukkan persentase hanya 15,3 \%. Tujuan penelitian ini adalah diketahuinya implementasi pemberian Air Susu Ibu (ASI) ekslusif di Kota Padang Panjang Tahun 2012. Penelitian ini menggunakan metode kualitatif. Pengumpulan data kualitatif dilakukan dengan mewawancarai 17 orang informan dan 7 orang FGD mengenai implementasipemberian ASI Ekslusifyaitu sosialisasi, ketersediaan akses informasi dan edukasi serta pemantauan dan evaluasi di Kota Padang Panjang. Hasil analisis kualitatif menunjukkan sosialisasi dilaksanakan karena merupakan tugas dari semua tenaga kesehatan. Akses terhadap informasi dan edukasi dilakukan melalui sosialisasi karena langsung dilakukan pada ibu dan bayi pada saat Posyandu. Pemantauan evaluasi dilakukan satu kali dalam sebulan di Posyandu, ini sesuai dengan pedoman surveilans program gizi.Diperlukan, pemantauan pelaksanaan IMD, pemantauan dengan metode kawal ASI, memberdayakan masyarakat (motivator) dengan di bentuknya kelompok pendukung ASI, dan membuat modul ASI untuk ibu-ibu yang mempunyai bayi. $\leftarrow 10$ pt, Times New Roman italic
\end{abstract}

Kata kunci: ASI ekslusif, sosialisasi, aksesinformasi, pemantauan

\begin{abstract}
Early Breastfeeding have a fundamental role in the survival of infants. Colostrum is rich in antibodies, growth, health and infant nutrition.Reducing morbidity and mortality for infants and toddlers, Early Initiation of Breastfeeding (IMD) has an important role for mothers in stimulating uterine contractions so as to reduce postpartum bleeding (postpartum). Breastfeeding in the long term can extend the birth interval because the amenorrhea period is longer, better restoration of nutritional status before the next pregnancy.According to the National Social and Economic Survey (SUSENAS), coverage of exclusive breastfeeding in infants up to 6 months in 2007 ranges from 28.6\%. Health Research Association (2010) shows the percentage of infants exclusively breastfed up to 6 months is only 15.3\%. The purpose of this study is known implementation of the exclusive breastfeeding. This study uses qualitative methods. Qualitative data collection is done by interview 17 people and 7 FGD informants regarding the implementation of the exclusive breastfeeding is information dissemination, availability of access to information and education, monitoring and evaluationin Padang Panjang.Implementingtheholderin accordancewith the guidelinesof nutrition programsnutritional surveillance. As well as monitoringand evaluationis done oncea monthat the Posyandu, which is in linewithnutritionalguidelines for the surveillanceprogram.It will be require own policy regarding exclusive breastfeeding, allocate special funds to increase exclusive breastfeeding, optimization of lactation clinic or lactation corner on the and public health service, improve the ability of workers with technical training for facilitators and labor counseling counselor, and monitoring the implementation of the IMD and empower community to form a support group in breastfeeding.
\end{abstract}

Keywords: exclusive breastfeeding, socialization, access to information, monitoring

*Korespondensi Author : Derry Trisna Wahyuni, Akademi Analis Kesehatan Putra Jaya Batam, trisna_derry@yahoo.com

\section{PENDAHULUAN}

Anak merupakan potensi dan penerus untuk mewujudkan kualitas dan keberlangsungan bangsa. Salah satu upaya mendasar untuk menjamin pencapaian tertinggi kualitas tumbuh kembangnya sekaligus memenuhi hak anak 
adalah pemberian makan yang terbaik sejak lahir hingga dua tahun. Makanan yang tepat bagi bayi adalah Air Susu Ibu (ASI) ekslusif yakni pemberian ASI saja segera setelah lahir sampai usia 6 bulan yang diberikan sesering mungkin ${ }^{1}$.

Menyusui sejak dini mempunyai dampak yang positif baik bagi ibu maupun bayinya. Bagi bayi, menyusui mempunyai peran penting yang fundamental pada kelangsungan hidup bayi, kolostrum yang kaya dengan zat antibodi, pertumbuhan yang baik, kesehatan dan gizi bayi. Mengurangi morbiditas dan mortalitas bayi dan balita, Inisiasi Menyusu Dini (IMD) mempunyai peran penting bagi ibu dalam merangsang kontraksi uterus sehingga mengurangi perdarahan pasca melahirkan (postpartum). Menyusui dalam jangka panjang dapat memperpanjang jarak kelahiran karena masa amenorhea lebih panjang, pemulihan status gizi yang lebih baik sebelum kehamilan berikutnya ${ }^{2}$.

Pada tahun 2001, setelah melakukan telaah artikel penelitian secara sistematik dan berkonsultasi dengan para pakar, WHO merevisi rekomendasi Air Susu Ibu (ASI) eksklusif dari 46 bulan menjadi 6 bulan. Hasil telaah artikel tersebut menyimpulkan bahwa bayi yang disusui secara eksklusif sampai 6 bulan umumnya lebih sedikit menderita penyakit gastrointestinal, dan lebih sedikit mengalami gangguan pertumbuhan. Definisi ASI eksklusif bermacam-macam tetapi definisi yang sering digunakan adalah definisi WHO yang menyebutkan ASI eksklusif adalah pemberian hanya ASI saja tanpa cairan atau makanan padat apapun kecuali vitamin, mineral atau obat dalam bentuk tetes atau sirup sampai usia 6 bulan. $^{3}$

Tujuan MDGs yang keempat adalah menurunkan angka kematian bayi dan balita menjadi 2/3 dalam kurun waktu 1990-2015. Menurut Survei Demogragfi Kesehatan Indonesia (SDKI) saat ini angka kematian balita 44 per 1.000 kelahiran hidup pada tahun 2007, sedangkan target MDGs yaitu 32 per 1.000 kelahiran hidup. Begitu pula dengan angka kematian bayi 34 per 1.000 kelahiran hidup pada periode yang sama, target MDGs tahun 2015 menjadi 23 per 1000 kelahiran hidup (Bappenas,
2010). Penyebab utama kematian bayi dan balita adalah diare dan pneumonia dan lebih dari $50 \%$ kematian balita didasari oleh kurang gizi. Pemberian ASI secara eksklusif selama 6 bulan dan diteruskan sampai usia 2 tahun disamping pemberian makanan pendamping ASI (MP ASI) secara adekuat terbukti merupakan salah satu intervensi efektif dalam menurunkan Angka Kematian Bayi (AKB)2 .

Tujuan MDGs yang kelima adalah peningkatan kesehatan ibu dengan target menurunkan angka kematian ibu sebesar 3/4 sampai tahun 2015. Menurut SDKI tahun 2007 Angka Kematian Ibu yaitu sebanyak 228, sedangkan target MDGs 2015 menjadi 102. Menyusui dapat menurunkan resiko pendarahan saat persalinan, kanker payudara, kanker ovarium dan kanker endometrosis. Selain itu dengan pemberian ASI eksklusif dapat menjadi alat kontrasepsi yang baik dan dapat menurunkan resiko kehamilan².

Menurut hasil Survei Sosial dan Ekonomi Nasional (Susenas), cakupan pemberian ASI eksklusif pada tahun 2007 berkisar 28,6 \%. Riset Kesehatan Dasar (2010) menunjukkan persentase bayi yang ASI eksklusif hanya $15,3 \%$. Fakta yang memprihatinkan pada pelaksanaan IMD hanya dilakukan pada 29,3\% bayi dan hanya $74,7 \%$ mendapat kolostrum. Bayi 0-7 hari $32 \%$ telah mendapat makanan pendamping ASI, diantaranya $85,8 \%$ diberi susu formula4.Di Sumatera Barat bayi usia 0-6 bulan $71,4 \%$ yang memberikan ASI ekslusif (Profil Kesehatan Indonesia, 2011: 139), cakupan ini belum mencapat target nasional yang telah ditetapkan tahun 2014 yaitu $80 \%$. $^{1}$

Pada bulan Maret 2012 Pemerintah menerbitkan Peraturan Pemerintah Republik Indonesia Nomor 33 tahun 2012 tentang pemberian air susu ibu eksklusif. Peraturan ini membahas mengenai kewajiban tenaga kesehatan yakni pelaksanan IMD, rawat gabung untuk ibu yang baru melahirkan dan akses terhadap informasi dan edukasi pemberian ASI ekslusif. Selain itu ada langkah-langkah dalam keberhasilan menyusui, serta sanksi bagi yang tidak melaksanakan pemberian ASI ekslusif.4 
Kota Padang Panjang berada padaposisi yang sangat strategis, yaitu dekatdengan ibu kota Propinsi. Kebijakan tersendiri tentang pemberian ASI ekslusif belum ada di Kota Padang Panjang. Berdasarkan paparan di atas maka penulis meneliti tentang bagaimana pelaksanaan kebijakan pemberian ASI ekslusif di Kota Padang Panjang tahun 2012. Ketik kalimat pertama paragraf pertama dari pengantar penelitian Anda. Ketikkan kalimat kedua dari paragraf pertama dari pengantar penelitian Anda. Ketikkan kalimat ketiga dari paragraf pertama dari pengantar penelitian Anda. Dll (minimal 3 kalimat dalam satu paragraf). ${ }^{1}$

Ketik kalimat pertama paragraf kedua dari pengantar penelitian Anda. Ketikkan kalimat kedua dari paragraf kedua dari pengantar penelitian Anda. Ketik kalimat ketiga paragraf kedua dari pengantar riset Anda.2 Dll (minimal 3 kalimat dalam satu paragraf). ${ }^{2} \leftarrow \quad I s i$ Pendahuluan: 11pt, Times New Roman
II. METODOLOGI $\leftarrow 11 p t$, Times New Roman bold

Penelitian ini merupakan penelitian kualitatif yang dilakukan dengan wawancara mendalam, Fokus Group Discussion (FGD) dan telaah dokumen.Penelitian ini di laksanakan di wilayah kerja Puskesmas Kota Padang Panjang. Penelitian juga dilakukan Rumah Sakit Umum Daerah (RSUD) Kota Padang Panjang, dan Bidan Praktek Swasta (BPS). Penelitian dilakukan mulai bulan pada bulan Juni sampai September 2012.

Pada penelitian kualitatif, sampel bukan dinamakan responden, tetapi sebagai informan dalam penelitian. Penentuan sumber data pada orang yang diwawancarai dilakukan secara purposive sampling, yaitu dipilih dengan pertimbangan dan tujuan tertentu5.Informan dalam penelitian ini dianggap paling tahu tentang apa yang diteliti, memegang jabatan strategis atau ahli dibidang kebijakan pemberian ASI Ekslusif sehingga memudahkan peneliti menjelajahi objek dan situasi yang di teliti.

Tabel 1. Informan, Jumlah dan Cara Pengumpulan Data

\begin{tabular}{|c|c|c|c|c|}
\hline \multirow[t]{2}{*}{ No } & \multirow[t]{2}{*}{ Informan } & \multirow[t]{2}{*}{ Jumlah } & \multicolumn{2}{|c|}{ Cara Pengumpulan Data } \\
\hline & & & $\begin{array}{l}\text { Wawancara } \\
\text { Mendalam }\end{array}$ & $\begin{array}{c}\text { Fokus Group } \\
\text { Diskusi }\end{array}$ \\
\hline 1 & Sekretaris Dinas Kesehatan & 1 orang & $\sqrt{ }$ & \\
\hline 2 & Kabid Upaya Peningkatan Kesehatan & 1 orang & $\sqrt{ }$ & \\
\hline 3 & Kabid sosial dan budaya Bappeda & 1 orang & $\sqrt{ }$ & \\
\hline 4 & Kepala Puskesmas Plus Bukit Surungan & 1 orang & $\sqrt{ }$ & \\
\hline 5 & Bidan pemegang prog KIA di Puskesmas & 2 orang & $\sqrt{ }$ & \\
\hline 6 & Pemegang program gizi di Puskesmas & 2 orang & $\sqrt{ }$ & \\
\hline 7 & Ketua IBI Kota Padang Panjang & 1 orang & $\sqrt{ }$ & \\
\hline 8 & Bidan Praktek Swasta & 2 orang & $\sqrt{ }$ & \\
\hline 9 & Karu Kebidanan RSUD Padang Panjang & 1 orang & $\sqrt{ }$ & \\
\hline 10 & Karu Perinatologi RSUD Padang Panjang & 1 orang & $\sqrt{ }$ & \\
\hline 11 & Kader Puskesmas & 7 orang & $\sqrt{ }$ & \\
\hline 12 & Ibu yang mempunyai bayi 6-11 bulan & 4 orang & & $\sqrt{ }$ \\
\hline & Jumlah & 24 orang & & \\
\hline
\end{tabular}

\section{HASIL DAN PEMBAHASAN}

\section{Sosialisasi}

Sosialisasi adalah sebuah proses penanaman atau transfer kebiasaan atau nilai dan aturan dari satu generasi ke generasi lainnya dalam sebuah kelompok atau masyarakat. Sosialisasi pemberian ASI ekslusif ini di lakukan terus-menerus.Sosialisasi juga dilakukan dalam bentuk penyuluhan yang di lakukan di Puskesmas 
ataupun di Posyandu, baik secara berkelompok maupun personal. Sosialisasi yang terus menerus di lakukan agar tenaga kesehatan selalu memberikan penyuluhan asi ekslusif, tidak memberikan susu formula dan masyarakat mengetahui manfaat dan keuntungan pemberian asi ekslusif dibandingkan dengan pemberian susu formula.Selanjutnya matriks triangulasi mengenai sosialisasi yang di dapatkan melalui dokumentasi, observasi dan wawancara mendalam sebagai berikut:Angka, bagan, foto, tabel harus diketik sesuai di bagian hasil.

Tabel 2. Matriks Triangulasi Sosialisasi Berdasarkan Telaah Dokumen,

Observasi dan Wawancara Mendalam

\begin{tabular}{lllll}
\hline Topik & Dokumen & Observasi & Wawancara & Analisis Triangulasi \\
\hline Sosialisasi & Laporan & Sosialiasi & Sosialisasi dilakukan di lintas & Sosialisasi dilakukan dengan \\
& bulanan & dilakukan pada & sektor dan langsung pada ibu-ibu & adanya kegiatan rutin bulanan \\
& Posyandu & saat posyandu & hamil sampai mempunyai bayi. & yang dilakukan seperti di \\
& pada ibu-ibu & Masyarakat sudah banyak yang & Posyandu, perlu menggunakan \\
& yang & mengetahui program ASI ekslusif. & strategi sosialisasi untuk \\
& mempunyai bayi & Sosialisasi juga dilakukan pada & perubahan perilaku masyarakat \\
& dan pada & kegiatan rutin dan termasuk & dan komitmen tenaga kesehatan \\
& kegiatan & dalam program gizi. & untuk peningkatan ASI ekslusif \\
& program gizi & & \\
\hline
\end{tabular}

Berdasarkan hasil penelitian di dapatkan bahwa ibu-ibu yang mempunyai bayi sudah di berikan penyuluhan di bantu dengan bidan-bidan PTT yang ada mengenai pemberian asi ekslusif. Penyuluhan seperti ini merupakan salah satu upaya sosialisasi tenaga kesehatan kepada ibuibu yang mempunyai bayi mengenai manfaat ASI ekslusif. Begitu juga di Rumah Sakit, sosialisasi mengenai ASI disampaikan pada saat ibu dan bayi dirawat gabung karena ibu dan tenaga kesehatan bisa langsung melakukan dan pemantauan yang dilakukan oleh bidan dan perawat agar tidak memberikan bayinya makanan lain selain ASI kecuali ada indikasi medis.
Penyuluhan dan sosialisasi dalam bentuk lain diharapkan dapat meningkatkan cakupan ASI ekslusif yang sekarang sudah mencapai 50,4\%.

\section{Ketersediaan Akses Informasi dan Edukasi}

Informasi mengenai ketersediaan akses informasi dan edukasi sudah dilakukan sesuai kebutuhan masyarakat. Informasi diberikan kepada ibu-ibu dengan adanya booklet yang dapat di bawa pulang ibu dan di baca oleh ibu-ibu di rumah.Selanjutnya matriks triangulasi mengenai ketersediaan informasi danedukasi yang di dapatkan melalui dokumentasi, observasi dan wawancara mendalam sebagai berikut:

Tabel 3. Matriks Triangulasi Ketersediaan Informasi dan Edukasi Berdasarkan Telaah Dokumen,

Observasi dan Wawancara Mendalam

\begin{tabular}{lllll}
\hline Topik & Dokumen & Observasi & Wawancara & Analisis Triangulasi \\
\hline Ketersediaan & Adanya pamflet, & Tersedianya & Informasi diberikan & Informasi dan edukasi \\
Informasi dan & booklet. Tidak ada & booklet, & di posyandu berupa & diberikan di posyandu karena \\
Edukasi & laporan atau daftar & spanduk, & penyuluhan dan & langsung dilakukan pada ibu \\
& hadir penyuluhan & penyuluhan & edukasi langsung & tapi hanya sebatas \\
& pemberian informasi & pada saat & pada ibu yang & memberikan informasi, masih \\
& dan edukasi & posyandu. & mempunyai bayi. & diperlukan bimbingan yang \\
& & & & intensif terutama ketika terjadi \\
& & & & permasalahan.
\end{tabular}


Berdasarkan hasil cakupan ASI ekslusif yang sudah mencapai 50,4\%, dapat disimpulkan bahwa hal ini bisa tercapai dengan tersedianya akses informasi dan edukasi yang ada pada fasilitas kesehatan atau sumber informasi lainnya. Informasi didapatkan bisa dimulai pada saat hamil, melahirkan sampai menyusui. Kegiatannyaberupa penyuluhan pada saat posyandu, tapi bimbingan ketika terjadi permasalahan masih kurang sehingga diperlukan terutama ketika terjadi permasalahan dalam menyusui.Ketersediaanakses terhadap informasi dan edukasi sangat diperlukan untuk pencapaian pelaksanaan kebijakan pemberian ASI ekslusif.

Berdasarkan hasil wawancara mendalam dengan pelaksana kebijakan di dapatkan informasi mengenai ketersediaan akses terhadap informasi ada pamflet, spanduk, kunjungan ke posyandu, waktu di posyandu di berikan penyuluhan mengenai asi ekslusif, kalau ibu hamil dengan kunjungan minimal 4 kali. Untuk edukasi pada ibu langsung di bimbing bagaimana cara menyusui yang baik.Menurut Hallenistilah bimbingan selalu dikaitkan dengan konseling, hal ini disebabkan karena bimbingan dan konseling merupakan suatu kegiatan yang integral. Konseling adalah merupakan salah satu teknik dalam pelayanan bimbingan diantara beberapa teknik yang lainnya, sedangkan bimbingan itu lebih luas dan konseling merupakan alat yang paling penting dari usaha pelayanan bimbingan. Walgito6mengatakan, konseling adalah bantuan yang diberikan pada seorang pasienuntuk memecahkan masalah kehidupannya dengan cara wawancara (face to face) dan dengan cara yang sesuai dengan keadaan yang dihadapi pasien untuk mencapai kesejahteraannya.7

Salah satu faktor yang mempengaruhi keberhasilan konseling dan bimbingan adalah alat peraga, jika alat peraga yang digunakan benda asli akan memberikan hasil yang maksimal, karena pesan yang disampaikan akan lebih dimengerti dan dipahami oleh ibu. Tetapi kenyataan dilapangan pelaksanaan konseling menyusui lebih sering menggunakan

ceramah dari pada demonstrasi akibat keterbatasan alat peraga. Pelaksanaan konseling yang baik, konselor perlu mengikuti langkah langkah atau prosedur tertentu. Pada umumnya, prosedur konseling terdiri dari beberapa fase antara lain persiapan, perencanaan treatment, Counseling in action dan follow up. Pelayanan bimbingan dan konseling adalah suatu profesi yang dapat memenuhi ciri-ciri dan persyaratan tersebut. Pengembangan profesi bimbingan dan konseling antara lain melalui standarisasi untuk kerja professional konselor, standarisasi penyiapan konselor, akreditasi, stratifikasi dan lisensi, dan pengembangan organisasi profesi8.

Pelaksanaan konseling menyusui di posyandu maupun dirumah-rumah masyarakat mayoritas dilaksanakan oleh bidan desa, alat peraga yang sering digunakan adalah leaflet dan gambar, sedangkan bagi ibu menyusui, praktek menyusuinya langsung di praktekkan keibu-ibu tersebut. Hal ini dirasakan masih kurang maksimal dalam pelaksanaanya.Penelitian Husnimenunjukan bahwa media promosi kesehatan (leaflet) efektif untuk menaikkan skor pengetahuan dan skor sikap ibu hamil tentrang IMD dan ASI eksklusif di Wilayah Kecamatan padangsidimpuan Selatan dengan nilai $\mathrm{p}=0,000$. Albernaz, et al. (2002) menyatakan bahwa hasil penelitian pada kelompok kontrol hampir dua kali lipat kemungkinan berhenti memberikan ASI sampai 4 bulan dibanding kelompok intervensi ( Prevalensi Ratio 1,$85 ; \mathrm{P}=0,04)$. Aidam, et al. (2005) menyatakan bahwa kelompok yang diberi konseling ASI eksklusif pada waktu pre-perinatal 90\% memberikan ASI eksklusif, kelompok yang diberi konseling ASI eksklusif pada waktu perinatal $74,5 \%$, kelompok pembanding $47,7 \%$ $(\mathrm{p}=0.008) .9$

Keterampilan konseling juga berguna saat berbicara dengan pasien atau klien dalam situasi lain. Manajemen laktasi merupakan segala daya upaya yang dilakukan untuk membantu ibu mencapai keberhasilan dalam menyusui bayinya. Manajemen laktasi melalui 3 tahap yaitu pada masa kehamilan (antenatal), sewaktu ibu dalam persalinan sampai keluar rumah sakit (perinatal), dan pada masa menyusui selanjutnya sampai anak berumur 2 tahun (postnatal). Jadi ketersediaan informasi dan edukasi yang terus 
menerus di sampaikan di mulai dari ketika ibu akan menikah sampai dengan melahirkan dan bayi berusia 6 (enam) bulan di perlukan untuk kelangsungan peningkatan pengetahuan mengenai pentingnya pemberian ASI ekslusif dengan kegiatan kawal ASI yang dilakukan secara simultan dilakukan oleh fasilitator, konselor dan motivator yang sudah menerima pelatihan.
Pemantauan dan Evaluasi

Pemantauan dan evaluasi dilakukan ke lapangan yang di lakukan oleh petugas puskesmas.Kegiatan pemantauan dan evaluasi ini di lakukan satu kali dalam sebulan. Pemantau dan evaluasiyang di lakukan oleh petugas gizi dengan menggunakan format yang sudah disediakan dari dinas kesehatan.

Tabel 4. Matriks Triangulasi Pemantauan dan Evaluasi Berdasarkan Telaah Dokumen, Observasi dan Wawancara Mendalam

\begin{tabular}{lllll}
\hline Topik & Dokumen & Observasi & Wawancara & Analisis Triangulasi \\
\hline Peman- & Format & Peman- & Pemantauan dan evaluasi & Pemantauan dan evaluasi \\
tauan dan & pencatatan & tauan dan & dilakukan satu kali dalam & dilakukan dengan wawancara \\
Evaluasi & dan & evaluasi & sebulan oleh petugas gizi dan & pada ibu yang mempunyai bayi \\
& pelaporan & dilaku & kegiatan dilakukan di & yang dilaksanakan satu kali \\
& & kan satu kali & Posyandu, hal ini sesuai & dalam sebulan. Hal ini sesuai \\
& sebulan di & dengan pedoman kementrian & pedoman kementrian kesehatan \\
& Posyandu . & kesehatan RI untuk monitoring & RI. Kegiatan preventif bisa di \\
& & dan evaluasi program gizi. Di & intensifkan dengan adanya \\
& & RSUD pemantauan terhadap & tenaga pelaksana khusus untuk \\
& & bayi dilakukan setiap 2-3 jam & pelaksanaan kawal ASI. Di \\
& & agar ibu memberikan ASInya & RSUD pemantaun dilakukan \\
& & sesuai kebutuhan bayi. & setiap 2-3 jam sesuai dengan \\
& & & kebutuhan bayi untuk \\
& & & memberikan ASI
\end{tabular}

Hasil penelitian didapatkan bahwa pemantauan dan evaluasi di lakukan dengan menanyakan langsung ke ibu-ibu yang mempunyai bayi. Apabila ibu tidak datang ke posyandu, biasanya petugas puskesmas dan kader langsung melakukan kunjungan ke rumah ibu yang mempunyai bayi. Pemantauan dan evaluasi dilakukan satu kali sebulan oleh petugas gizi dan terintegrasi dalam program kesehatan ibu dan anak. Menurut hasil penelitian yang didapatkan, dengan kegiatan pemantauan yang dilakukan satu kali sebulan oleh tenaga Puskesmas ini sudah mencapai cakupan ASI ekslusif sebanyak 50,4 \%. Di Rumah Sakit pemantauan dilakukan setiap 2-3 jam pada bayi yang baru dilahirkan begitu juga pada bayi yang sakit dianjurkan agar ibu untuk memberikan ASI setiap 2-3 jam, apabila bayi tidak bisa menyusui langsung, maka ASI dapat diperah dan diberikan dengan menggunakan sonde.

\section{IV.SIMPULAN DAN SARAN SIMPULAN}

1. Sosialisasi dilaksanakan terus menerus karena merupakan tugas dari semua tenaga kesehatan terutama pelaksana program. Kegiatan dilakukan setiap bulan seperti di Posyandu yang merupakan bagian dari kegiatan gizi dan tergabung dalam program KIA.

2. Akses terhadap informasi dan edukasi dilakukan melalui sosialisasi karena langsung dilakukan pada ibu dan bayi pada saat Posyandu.

3. Pemantauan dan evaluasi dilakukan oleh tenaga pemegang program gizi dengan memantau pelaksanaan satu kali dalam sebulan di Posyandu, hal ini sesuai dengan pedoman surveilans program gizi. 


\section{Dinas Kesehatan}

1. Membuat strategi baru untuk sosialisasi seperti ruang konseling laktasi di Puskesmas dihiasi dengan poster, pamflet, lembar balik, alat bantu konseling dan video ASI, pembuatan video dokumentar IMD, mengadakan jambore kader ASI, lomba paduan suara konselor dan motivator ASI, ikrar ibu hamil mendukung IMD dan ASI eksklusif, baliho besar dipasang di ruangruang publik dengan pesan pemberian ASI, baliho yang lebih kecil juga dipasang di setiap Puskesmas, tokoh agama memberikan pesan tentang ASI dalam kegiatan religi agama, dan konseling pranikah oleh KUA diselipkan untuk konsultasi ke klinik laktasi.

2. Akses terhadap informasi dan edukasi dilakukan melalui strategi sosialisasi yang melibatkan semua team pelaksana ASI ekslusif seperti melakukan konseling dan pendampingan kawal ASI.

3. Pemantauan dan evaluasi dilakukan oleh team pelaksana (fasilitator, konselor, motivator) pada masing-masing kelurahan dan dilakukan satu kali seminggu dengan metode kawal ASI.

\section{Puskesmas}

Membentuk kelompok pendukung ASI bekerja sama dengan PKK mengelola potensi yang ada di masyarakat seperti arisan mingguan dengan mengumpulkan dana peduli terhadap peningkatan pemberian ASI ekslusif dengan memberikan reward bagi yang berhasil melaksanakannya.

\section{Rumah Sakit Umum Daerah}

1. Membuat strategi baru untuk sosialisasi seperti ruang konseling laktasi di RumahSakit dihiasi dengan poster, pamflet, lembar balik, alat bantu konseling dan video ASI, pembuatan video dokumentar IMD, mengadakan jambore kader ASI, lomba paduan suara konselor dan motivator ASI, ikrar ibu hamil mendukung IMD dan ASI eksklusif, baliho besar dipasang di ruangruang publik dengan pesan pemberian ASI, baliho yang lebih kecil juga dipasang di setiap RumahSakit.

2. Akses terhadap informasi dan edukasi dilakukan melalui strategi sosialisasi yang melibatkan semua team pelaksana ASI ekslusif seperti melakukan konseling dan pendampingan kawal ASI yang dilaksanakan setiap 2-3 jam selama perawatan.

3. Pemantauan dan evaluasi dilakukan oleh team pelaksana (fasilitator dan konselor) dilakukan setiap hari.

\section{Bagi Istitusi Pendidikan}

Mengintegrasikan materi mengenai ASI eksklusif pada kurikulum pendidikan formal dan non formal bagi tenaga Kesehatan.

\section{Bagi Peneliti Selanjutnya}

Dikembangkannya penelitian untuk mengkaji motivasi tenaga kesehatan dalam melaksanakan kebijakan pemberian ASI ekslusif.

\section{UCAPAN TERIMA KASIH}

Ucapan terima kasih kami sampaikan kepada Pemerintah Kota Padang Panjang, Dinas Kesehatan, Puskesmas, dan RSUD Kota Padang Panjang yang telah banyak membantu dalam penelitian ini.

\section{REFERENSI}

1. Kementrian Kesehatan RI. 2010. Strategi Peningkatan Makanan Bayi Dan Anak. Jakarta: Kementerian Kesehatan RI

2. Pratiwi, Rini. Analisis Formulasi dan Implementasi Kebijakan Peraturan Daerah Nomor 7 Tahun 2008 tentang Inisiasi Menyusui Dini dan ASI ekslusif Kabupaten Klaten 2011 . Universitas Dipenogoro.;2011

3. WHO. 2002 . Nutrient adequacy of exclusive breastfeeding for the term infant during the first six months of life.

4. Peraturan Pemerintah Republik Indonesia No 33. Pemberian ASI Ekslusif. 2012. Jakarta

5. Sugiyono, Prof.Dr,. Metode Penelitian Kuantitatif dan Kualitatif. 2002. R\&D, Alfabeta. Bandung.

6. Walgito, B. 2010. Bimbingan Konseling (Studi \& Karier), ANDI, Yogyakarta. 
7. Hallen, A. 2002. Bimbingan dan Konseling dalam Islam, Jakarta; Ciputat Pers.

8. Prayitno. 2011. Panduan Kegiatan Pengawasan Bimbingan dan Konseling di Sekolah. Jakarta: PT Rineka Cipta.

9. Husni, N.A. 2010. Efektivitas Media Promosi Kesehatan(leaflet) dalam Perubahan Pengetahuan dan Sikap ibu Hamil tentang Inisiasi Menyusui Dini (IMD) dan ASI Eksklusif Kota Padang Sidempuan. Tesis Universitas Sumatera Utara Medan 